\title{
PENGGUNAAN BILINGUALISME PADA MASYARAKAT YANG BERWIRAUSAHA
}

\author{
Ratna Dewi Kartikasari \\ Pendidikan Bahasa dan Sastra Indonesia Universitas Muhammadiyah Jakarta \\ g4lih_58@yahoo.com

\begin{abstract}
ABSTRAK
Penelitian ini dilatarbelakangi oleh masyarakat yang sudah jarang memakai bahasa monolingual (1 bahasa). Namun dalam kehidupan sehari-hari, masih banyak masyarakat yang memakai dua bahasa (bilingual). Setidaknya masyarakat yang menggunakan bahasa daerah dan bahasa Indonesia. Penelitian ini dilakukan di daerah Kelurahan Sukamaju, Kecamatan Cilodong. Hasil penelitian menunjukkan situasi kebahasaan pada masyarakat tutur daerah Jawa, Mandailing, Padang, dan Sunda di daerah Cilodong ditandai dengan adanya kontak bahasa yang menjadikan masyarakat tutur Jawa, Mandailing, Padang, dan Sunda di daerah Cilodong sebagai masyarakat yang bilingual. Data dari peristiwa tutur dalam berbagai ranah pada penelitian ini memperlihatkan bahwa kode yang berwujud bahasa yang dominan digunakan dalam komunikasi pada masyarakat tutur Jawa, Mandailing, Padang, dan Sunda di daerah CIlodong terdiri atas beberapa kode. Kode tersebut berupa Bahasa Indonesia (BI), Bahasa Jawa (BJ), Bahasa Mandailing (BM), Bahasa Padang/Minang (BP), dan Bahasa Sunda (BS).
\end{abstract}

Kata kunci: bilingualisme, masyarakat tutur, kode bahasa

\section{PENDAHULUAN}

Pada umumnya masyarakat di dunia pada zaman sekarang ini memiliki bilingualisme (kedwibahasaan) untuk berkomunikasi. Sarana komunikasi yang paling penting pada masyarakat adalah bahasa. Oleh karena kedudukannya yang sangat penting, maka membuat bahasa tidak lepas dari kehidupan manusia dan selalu ada pada aktivitas dan kehidupannya Negara Indonesia merupakan negara multietnis yang memiliki beratus-ratus ragam bahasa. Dengan adanya bermacammacam bahasa daerah di Indonesia, menjadikan bahasa daerah menjadi salah satu penunjuk identitas suatu etnis. Walaupun memiliki bermacam-macam bahasa daerah, salah satu ciri yang menonjol dari identitas bangsa Indonesia yaitu adanya bahasa persatuan, bahasaIndonesia. Dalam masyarakat tutur, bahasa mempunyai ragam atau variasi yang digunakan oleh masyarakat penuturnya. 
Website : https://jurnal.umj.ac.id/index.php/penaliterasiEmail : penaliterasi@umj.ac.id

Dengan latar belakang sosial, budaya, dan situasi, masyarakat tutur dapat menentukan penggunaan bahasanya. Dalam pandangan Sosiolinguistik, situasi kebahasaan pada masyarakat bilingual (dwibahasa) ataupun multilingual (multibahasa) sangat menarik untuk diteliti.

Sebagai akibat dari situasi kedwibahasaan pada masyarakat tutur pendatang di daerah Cilodong, pengamatan menunjukkan bahwa terdapat faktor-faktor penentu dalam pengambilan keputusan pada sebuah tuturan. Selain itu, dengan adanya kontak bahasa di daerah Cilodong, muncul pula gejala alih kode dan campur kode pada penuturnya. Kedua gejala kebahasaan tersebut-alih kode dan campur kode-mengacu pada peristiwa di mana pada saat berbicara, seorang penutur memasukkan unsur-unsur bahasa lain ke dalam bahasa yang sedang digunakannya. Fenomena tersebut bisa terjadi di sembarang tempat, baik itu di rumah tangga, tempat umum, sekolah, dan lain sebagainya.

Objek penutur dalam penelitian ini adalah penutur yang merupakan pendatang dari Mandailing, Jawa, dan Padang yang menggunakan bahasa daerah masingmasing. Pembatasan penutur dari luar daerah Cilodong didasarkan pada alasan bahwa bahasa ibu/ bahasa pertama (B1) yang mereka miliki bukanlah bahasa lokal yang ada di daerah Cilodong. Ketika para pendatang dari daerah tersebut datang ke daerah Cilodong, maka terjadilah kontak bahasa yang memungkinkan munculnya alih kode dan campur kode.

Pemilihan tuturan oleh penutur pendatang di daerah Cilodong dalam penelitian ini didasarkan atas pertimbangan-pertimbangan misalnya, Pertama, sejauh pengamatan penulis belum pernah ada penelitian yang secara khusus memfokuskan pengkajian pada pemilihan kode pada masyarakat pendatang dari daerah yang disebutkan di atas dalam penuturannya dengan masyarakat di Cilodong. Kedua, dikaji dari pandangan Sosiolinguistik, kontak bahasa yang terjadi pada masyarakat dwibahasa seperti dengan adanya bahasa Indonesia dan bahasa daerah pada Penelitian ini bertujuan untuk memperoleh pemahaman yang mendalam tentang alih kode dan campur kode pada tuturan masyarakat bilingual di wilayah Cilodong, Depok. Penelitian tentang alih kode dan campur kode ini bermanfaat dalam beberapa hal. Pertama, dengan penelitian ini diharapkan dapat diperoleh deskripsi tentang pemilihan alih kode, dan campur kode pada masyarakat multibahasa di Indonesia, khususnya pada tuturan masyarakat Mandailing, Padang, Jawa, dan Sunda di daerah Cilodong. Kedua, melalui deskripsi tentang alih kode dan campur kode yang diungkap melalui penelitian ini diharapkan bermakna bagi upaya pembinaan dan pengembangan ilmu bahasa, baik yang menyangkut bahasa Indonesia maupun bahasa- bahasa lainnya.

Lokasi penelitian ini adalah Kelurahan Sukamaju, Kecamatan Cilodong, Kota Depok. Sedangkan yang dimaksud masyarakat Mandailing, Padang, Jawa, dan Sunda dalam penelitian ini adalah masyarakat tutur pendatang yang berasal dari daerah tersebut dan menggunakan bahasa daerah mereka sebagai B I (Bahasa pertama/ibu). Bahasa tersebut diketahui melalui tuturan yang digunakannya. 
Ratna Dewi Kartikasari : Penggunaan Bilingualisme Pada Masyarakat Yang Berwirausaha...

Website : https://jurnal.umj.ac.id/index.php/penaliterasiEmail : penaliterasi@umj.ac.id

Istilah kode dipakai untuk menyebut

salah satu varian di dalam hierarki kebahasaan, sehingga selain kode yang mengacu kepada bahasa (seperti bahasa Inggris, Belanda, Jepang, Indonesia), juga mengacu kepada variasi bahasa, seperti varian regional (bahasa Jawa dialek Banyuwas, Jogja-Solo, Surabaya), juga varian kelas sosial disebut dialek sosial atau sosiolek (bahasa Jawa halus dan kasar), varian ragam dan gaya dirangkum dalam laras bahasa (gaya sopan, gaya hormat, atau gaya santai), dan varian kegunaan atau register (bahasa pidato, bahasa doa, dan bahasa lawak). Kenyataan seperti di atas menunjukkan bahwa hierarki kebahasaan dimulai dari bahasa pada level paling atas diikuti dengan kode yang terdiri atas varian, ragam, gaya, dan register.

\section{Alih kode}

Alih kode adalah peristiwa peralihan dari satu kode ke kode yang lain (Chaer dan Agustina, 2010: 107). Misalnya penutur menggunakan bahasa Indonesia beralih menggunakan bahasa Jawa. Alih kode merupakan salah satu aspek ketergantungan bahasa dalam masyarakat multilingual. Dalam masyarakat multilingual sangat sulit seorang penutur mutlak hanya menggunakan satu bahasa. Dalam alih kode masing-masing bahasa masih cenderung mendukung fungsi masingmasing sesuai dengan konteksnya. Suwito (1983: 100) membagi alih kode menjadi dua yaitu:

a. Alih kode ekstern Bila alih bahasa, seperti dari bahasa Indonesia beralih ke bahasa Inggris atau sebaliknya.

b. Alih kode intern
Bila alih kode berupa alih varian, seperti dari bahasa Jawa ngoko berubah ke krama.

Beberapa faktor yang menyebabkan alih kode antara lain sebagai berikut.

1) Penutur

Seorang penutur kadang dengan sengaja beralih kode terhadap mitra tutur karena suatu tujuan. Misalnya mengubah situasi dari resmi menjadi tidak resmi atau sebaliknya.

2) Mitra Tutur

Mitra tutur yang latar belakang kebahasaannya sama dengan penutur biasanya beralih kode dalam wujud alih varian dan bila mitra tutur berlatar belakang kebahasaan berbeda cenderung alih kode berupa alih bahasa.

3) Hadirnya Penutur Ketiga

Untuk menetralisasi situasi dan menghormati kehadiran mitra tutur ketiga, biasanya penutur dan mitra tutur beralih kode, apalagi bila latar belakang kebahasaan mereka berbeda.

4) Pokok Pembicaraan

Pokok Pembicaraan atau topik merupakan faktor yang dominan dalam menentukan terjadinya alih kode. Pokok pembicaraan yang bersifat formal biasanya diungkapkan dengan ragam baku, dengan gaya netral dan serius dan pokok pembicaraan yang bersifat informal disampaikan dengan bahasa takbaku, gaya sedikit emosional, dan serba seenaknya. 
Ratna Dewi Kartikasari : Penggunaan Bilingualisme Pada Masyarakat Yang Berwirausaha...

Website : https://jurnal.umj.ac.id/index.php/penaliterasiEmail : penaliterasi@umj.ac.id

5) Untuk membangkitkan rasa humor

Biasanya dilakukan dengan alih varian, alih ragam, atau alih gaya bicara.

6) Untuk sekadar bergengsi

Walaupun faktor situasi, lawan bicara, topik, dan faktor sosio- situasional tidak mengharapkan adanya alih kode, terjadi alih kode, sehingga tampak adanya pemaksaan, tidak wajar, dan cenderung tidak komunikatif.

\section{Campur Kode}

Campur kode terjadi apabila seorang penutur menggunakan suatu bahasa secara dominan mendukung suatu tuturan disisipi dengan unsur bahasa lainnya (Chaer dan Agustina, 2010: 115). Hal ini biasanya berhubungan dengan karakteristik penutur, seperti latar belakang sosial, tingkat pendidikan, rasa keagamaan. Biasanya ciri menonjolnya berupa kesantaian atau situasi informal. Namun bisa terjadi karena keterbatasan bahasa, ungkapan dalam bahasa tersebut tidak ada padanannya, sehingga ada keterpaksaan menggunakan bahasa lain, walaupun hanya mendukung satu fungsi. Campur kode termasuk juga konvergense kebahasaan (linguistic convergence). Campur kode dibagi menjadi dua, yaitu:

1) Campur kode ke dalam (innercode- mixing), campur kode yang bersumber dari bahasa asli dengan segala variasinya.
2) Campur kode ke luar (outer codemixing): campur kode yang berasal dari bahasa asing.

Latar belakang terjadinya campur kode dapat digolongkan menjadi dua, yaitu:

a. Sikap, latar belakang sikap penutur.

b. Kebahasaan, latar belakang keterbatasan bahasa, sehingga ada alasan identifikasi peranan, identifikasi ragam, dan keinginan untuk menjelaskan atau menafsirkan.

\section{Bilingualisme}

Masyarakat bahasa adalah masyarakat yang menggunakan satu bahasa yang disepakati sebagai alat komunikasinya. Dilihat dari bahasa yang digunakan dalam suatu masyarakat bahasa, masyarakat bahasa yang menggunakan satu bahasa da nada masyarakat yang menggunakan dua bahasa atau lebih. Masyarakat bahasa yang menggunakan satu bahasa disebut masyarakat monolingual. Sedangkan masyarakat bahasa yang menggunakan dua bahasa atau lebih disebut masyarakat bilingual.

Di era maju dan modern ini barangkali jarang ditemukan masyarakat bahaasa monolingual. Akan tetapi, mungkin masih ada ditemukan misalnya, daerah- daerah terpencil. Ada juga kemungkinan masyarakat generasi lama yang karena satu dan lain hal tidak memiliki kesempatan belajar bahasa lain selain bahasa daerahnya. Setelah menjadi generasi tua, mereka menjadi masyarakat monolingual. Namun dalam kehidupan 
Ratna Dewi Kartikasari : Penggunaan Bilingualisme Pada Masyarakat Yang

Berwirausaha...

Website : https://jurnal.umj.ac.id/index.php/penaliterasiEmail : penaliterasi@umj.ac.id

sehari-hari, ada pula masyarakat

bilingual. Setidaknya masyarakat yang menggunakan bahasa daerah dan bahasa Indonesia. Misalnya, masyarakat yang menggunakan bahasa Sunda dan bahasa Indonesia, bahasa Banjar dengan bahasa Indonesia dan bahasa Jawa dan bahasa Indonesia.

Istilah bilingualisme dalam bahasa Indonesia disebut juga kedwibahasaan (Chaer dan Agustina, 2010: 85). Dari istilah secara harfiah sudah dapat dipahami apa yang dimaksud dengan bilingualisme itu, yaitu berkenaan dengan penggunaan dua bahasa atau dua kode bahasa. Secara secara sosiolinguitik secara umum, bilingualisme diartikan sebagai penggunaan dua bahasa. atau lebih seorang penutur dalam pergaulannya dengan orang lain secara bergantian (Mackey dalam Chaer dan Agustina, 2010: 87). Untuk dapat menggunakan dua bahasa tentunya seseorang harus menguasai dua bahasa itu. Pertama, bahasa itu sendiri atau bahasa pertamanya (B I) dan bahasa yang kedua (B II). Orang yang menggunakan bahasa kedua tersebut disebut orang yang bilingual (kedwibahasaan). Sedangkan kemampuan untuk menggunakan dua bahasa disebut bilingualitas. Selain istilah bilingualisme juga digunakan istilah multibilingualisme yakni keadaan yang digunakan lebih dari dua bahasa oleh seseorang dalam pergaulannya dengan orang lain secara bergantian (Chaer dan Agustina, 2010: 84). Dengan demikian campur kode terjadi karena adanya hubungan timbal balik antara peranan penutur, bentuk bahasa, dan fungsi bahasa. Masyarakat yang bilingual dalam

\begin{abstract}
komunikasi berbahasa dengan masyarakat sekitar berkenaan dengan siapa yang berkomunikasi dengan mereka. Penggunaan bahasa dalam berkomunikasi harus sesuai dengan situasi yang ada, dan pilihan kode ketika berkomunikasi sangat memungkinkan lancarnya proses komunikasi. Dengan adanya kontak bahasa antara masyarakat Jawa, Sunda, Mandailing, dan Padang dari daerah yang sama dan masyarakat yang tinggal di daerah Cilodong, terjadi pula alih kode, campur kode, dan bilingualism yang didasarkan pada barbagai faktor sosial. Hipotesis faktor-faktor sosial penentu alih kode antara lain kehadiran orang ketiga dan peralihan pokok pembicaraan. Pada campur kode, faktorfaktor sosial penentu adanya campur kode adalah keterbatasan penggunaan kode dan penggunaan istilah yang lebih populer. Kemudian dalam proses komunikasi, seorang yang bilingual dilihat dari situasi dengan siapa ketika mereka berbicara apakah dengan orang yang berasal dari daerah yang sama atau dari lingkungan lain atau lingkungan setempat.
\end{abstract}

\section{METODE PENELITIAN}

Penelitian ini menggunakan pendekatan Sosiolinguistik dan merupakan sebuah penelitian lapangan. Pendekatan Sosiolinguistik tersebut secara metodologis dipusatkan pada komunikasi yang dikembangkan dengan menggunakan data kualitatif. Tuturan yang menjadi data penelitian ini terealisasi di dalam penggalan tuturan masyarakat tutur Jawa, Mandailing, Sunda, dan Padang di daerah Cilodong.

Metode observasi pada penelitian ini menggunakan dua teknik lanjutan, 
Ratna Dewi Kartikasari : Penggunaan Bilingualisme Pada Masyarakat Yang Berwirausaha...

Website : https://jurnal.umj.ac.id/index.php/penaliterasiEmail : penaliterasi@umj.ac.id yaitu teknik simak libat cakap dan teknik simak bebas libat cakap. Dalam teknik simak libat cakap, peneliti berpartisipasi dalam menyimak dan terlibat dalam pembicaraan tersebut. Sedangkan pada teknik bebas libat cakap, peneliti tidak terlibat atau tidak ikut serta dalam suatu peristiwa tutur, namun hanya mendengarkan tuturan dari sebuah peristiwa tutur. Dalam penelitian ini, peneliti hanya menggunakan teknik mendengarkan tanpa terlibat dengan percakapan tetapi peneliti berusaha mencari tahu maksud dari yang diucapkan oleh penutur.

\section{HASIL DAN PEMBAHASAN}

Pada data peristiwa tutur dalam berbagai ranah pada penelitian ini memperlihatkan bahwa kode yang berwujud bahasa yang dominan digunakan dalam komunikasi pada masyarakat tutur Jawa, Mandailing, dan Padang di daerah Cilodong terdiri atas beberapa kode. Dari penelitian tersebut, kode yang ditemukan adalah kode yang berupa Bahasa Indonesia (BI), Bahasa Jawa (BJ), Bahasa Mandailing (BM), Bahasa Padang (BP). Keempat kode tersebut muncul akibat adanya peristiwa kontak bahasa antara masyarakat tutur daerah tersebut dengan masyarakat tutur yang menggunakan bahasa Indonesia.

Berikut penggunaan metode korelasi dalam peristiwa campur kode dan alih kode dalam peristiwa tutur.

\section{Masyarakat Jawa}

Konteks: Pembeli orang Jawa sedang berbelanja di warung yang juga orang Jawa.

Pembeli: $\mathrm{Bu}$, wonten indomie napa mboten? Regine pinten? $(\mathrm{Bu}$, ada indomie tidak? Harganya berapa?)

tigangewu. (Ada indomie, harganya tiga ribu.)

Pembeli: tumbas kaleh mawon kalean pasta giginipun setunggal ingkang ageng. (Beli dua saja sama pasta giginya satu yang besar)

Penjual: Nggih (iya)

Penggunaan kata indomie dan pasta gigi pada peristiwa tutur tersebut merupakan fenomena adanya campur kode pada tuturan dengan kode dasar Bahasa Jawa (BJ). Kata indomie dan pasta gigi pada tuturan tersebut merupakan campur kode dari kode Bahasa Indonesia (BI).

\section{Masyarakat Mandailing}

Orang I: Nangkin ke au manabusi nga pasuo, ahirna mulan au mulak tubagas. (Tadi saya pergi mencari soto, tetapi tidak ketemu, akhirnya saya balik lagi.)

Orang II: Nga uboto sanga aha utabusi be? (Terus jadinya beli apa?)

OrangI: Ujung-ujung na manabusi bakso. (Ujung-ujungnya beli bakso.)

Tiba-tiba datang pembeli yang menggunakan bahasa Indonesia.

Orang III: Abang beli terigu, telor, sama minyak, dong.

Orang 1: Berapa?

Dilihat dari percakapan di atas bisa diketahui bahwa pada saat peristiwa tutur tesebut sedang berlangsung adanya peristiwa campur kode dan alih kode, pada kata bakso dalam kalimat di atas bahwa kata bakso menggunakan Bahasa Indonesia (BI) karena tidak ada bahasa Mandailing 
Ratna Dewi Kartikasari : Penggunaan Bilingualisme Pada Masyarakat Yang Berwirausaha...

Website : https://jurnal.umj.ac.id/index.php/penaliterasiEmail : penaliterasi@umj.ac.id

yang mengartikan bakso, dan kemudian pada kalimat selanjutnya bahwa terjadinya alih kode. Pada saat orang kesatu dan orang kedua sedang berbincang mereka menggunakan bahasa daerahnya yaitu bahasa Mandailing, kemudian setelah ada orang ketiga maka orang satu langsung beralih menggunakan bahasa Indonesia yang memang bahasa Nasional bangsa Indonesia dalam peristiwa tutur apabila mereka berbeda daerah dan hanya bahasa Indonesia yang menjadi pedoman dalam berbahasa.

\section{Masyarakat Padang}

Bapak: Bundo alah di bali bahan-bahan kadai alun, anan di bali cako? (Ibu sudah beli bahan-bahan warung belum? Apa saja tadi yang dibeli?)

Ibu: Alah pak, cako alah pasan jo uda pasa, talua ciek peti, indomie sapuluh karduih, minyak duo drum, jo terigi limo karuang. (Sudah pak, tadi sudah pesan sama abang pasar, telur satu peti, indomie sepuluh kardus, minyak dua drum, sama terigu lima karung.)

Bapak: Oh jadih $\mathrm{Bu}$, bara total sadonya? (Oh ya sudah $\mathrm{Bu}$, totalnya berapa semua?)

Ibu: Satu juto lima ratuih, Pak. (Satu juta lima ratus, Pak.)

Bapak: Jadih kalau alah tibo, agiah tau ka bapak yo. (Ya sudah Bu, kalau sudah datang barangnya katakana pada bapak, ya.)

Ibu: Iyo, Pak. (Iya, Pak.)

Dilihat dari percakapan di atas adanya campur kode yang digunakan dalam proses berkomunikasi, adanya kata-kata dalam bahasa Indonesia seperti bahanbahan, indomie, minyak, dan satu yang tidak bisa di terjemahkan ke dalam bahasa Padang (Minang). Sehingga percakapan tersebut menggambarkan bahwa masyarakat Indonesia sering sekali mencampurkan antara bahasa ibu/bahasa daerah mereka dengan bahasa Indonesia.

\section{Masyarakat Sunda}

Pembeli: Mang, ieu peuyeum sabaraha pangaosna? (Bang, itu tape berapa harganya?)

Pedangang: $\mathrm{Nu}$ eta mah dua ribu teh, tos amis nu eta mah, parantos asak. (Yang itu dua ribu mbak, sudah manis karena sudah matang.)

Pembeli: Oh muhun, abdi meser sakilo atuh mang. (Oh, iya saya beli sekilo.)

Dilihat dari percakapan di atas walaupun berada dilingkungan masyarakat betawi, sesama orang sunda masih tetap menggunakan bahasa ibu mereka untuk berkomunikasi dengan orang sesame daerahnya.

Kemudian dari analisis yang dilihat dari angket yang telah di isi bahwa masyarakat tutur daerah Jawa, Mandailing, Padang, dan Sunda yang berada di lingkungan masyarakat Sukamaju Cilodong memang merupakan masyarakat yang bilingualisme, sebab mereka menguasai lebih dari satu bahasa. Bahasa pertama/bahasa ibu (B I) mereka kuasai sejak kecil yang memang diajarkan oleh keluarga mereka sendiri yang memang merupakan masyarakat asli daerah sana dan mereka yang memang lahir dan besar di sana. Jadi hal tersebut mempengaruhi mereka dalam mempelajari bahasa daerah asalnya. Kemudian ketika mereka tinggal di lingkungan lain yang otomatis bukan daerah asal mereka dan mereka beralih dalam 
Website : https://jurnal.umj.ac.id/index.php/penaliterasiEmail : penaliterasi@umj.ac.id

penggunaan bahasa yang digunakan dalam berkomunikasi dengan masyarakat sekitar. Kode Bahasa Indonesia (BI) dalam masyarakat tutur di aerah Sukamaju Cilodong. BI merupakan kode yang paling dominan sebagai hahasa persatuan. Hal itu disebabkan kenyataan situasi kebahasaan di daerah Cilodong yang mayoritas masyarakatnya merupakan masyarakat pendatang dari berbagai daerah di Indonesia yang memiliki bahasa daerah yang berbedabeda.

\section{KESIMPULAN}

$\begin{array}{llr}\text { Berdasarkan } & \text { hasil } & \text { yang } \\ \text { diungkapkan dalam } & \text { penelitian } & \text { ini, } \\ \text { maka disimpulkan } & \text { bahwa } & \text { profil }\end{array}$ situasi kebahasaan pada masyarakat tutur daerah Jawa, Mandailing, Padang, dan Sunda di daerah Cilodong ditandai dengan adanya kontak bahasa yang menjadikan masyarakat tutur Jawa, Mandailing, Padang, dan Sunda di daerah Cilodong sebagai masyarakat yang bilingual. Data dari peristiwa tutur dalam berbagai ranah pada penelitian ini memperlihatkan bahwa kode yang berwujud bahasa yang dominan digunakan dalam komunikasi pada masyarakat tutur Jawa, Mandailing, Padang, dan Sunda di daerah CIlodong terdiri atas beberapa kode. Kode tersebut berupa Bahasa Indonesia (BI), Bahasa Jawa (BJ), Bahasa Mandailing (BM), Bahasa Padang/Minang (BP), dan Bahasa Sunda (BS).

\section{REFERENSI}

Chaer, Abdul dan Agustina, Leoni. 2010. Sosiolinguistik: Perkenalan Awal. Jakarta: Rineka Cipta.

Mackey, W.P. 1970. "The Description of Bilingualism" dalam J.A Fishman (Ed.) 1970.

Suwito. 1983. Sosiolinguistik: Teori dan Problema. Surakarta: Kenary Offset. 